\title{
Empirical Study of High-tech Industry Cluster in Shaanxi Province
}

\author{
Wenyuan Wang \\ School of Humanities, Economics and Law \\ Northwest Polytechnical University \\ Xi'an,P.R.China, +8618663682672 \\ yane-free@163.com
}

\author{
Jin Yang \\ School of Humanities, Economics and Law \\ Northwest Polytechnical University \\ Xi'an,P.R.China, +8613572239579 \\ jinyang@nwpu.edu.cn
}

\begin{abstract}
The development of the high-tech industry, is an important foundation for the country to enhance industrial competitiveness, and is also one of the important manifestation of a country's composite national power. In order to research mechanisms, which promoted high-tech industrial cluster, this paper used the time series data model with the Eviews software. At the same time, I undertook deepening and comprehensive study on the cluster performance by regression analysis, and then I screened out three major factors, that effect the development of Shaanxi high-tech industry cluster. Finally, I analysis the status of Shaanxi high-tech industry cluster and put forward the countermeasures for it.
\end{abstract}

Keywords- high-tech industries; cluster performance; influencing factor

\section{INTRODUCTION}

The level of high-tech industry agglomeration is a significant respect which measures the industrial development, therefore, it's of great theoretical and practical significance, to research various factors and mechanisms promoting high-tech industrial agglomeration, for formulating industrial policies and regulations, the establishment and development of the new industry district, and using the advantages of industrial clusters to develop region economy.

The concept of high-tech industry cluster stems from the concept of industrial clusters.Simply speaking, high-tech industrial cluster refers to companies and organizations gathered in a certain area which is mutual associated, complementary and competing in the field of high-tech. Forming around universities or research institutions typically, this group is a organism fulling of innovation ${ }^{[1]}$. Industry concentration level is affected by many factors, not only economic geographical factors, new economic geography factors, but also the government related policy factors, such as the quantity of developers, capital investment, finance, research and development funds invested in financial institutions, education, science and technology, the economic development level in the local area, etc ${ }^{[2]}$.

When exploring the competitiveness of Canadian biotechnology industry cluster, Sabourin\&Pinsonneaut ${ }^{[3]}$ pointed out that the high-quality human resources play a key

This paper is supported by the National Natural Science Foundation of China (No.70803040); the Natural Science Fund of Shaanxi

Province(No.2011JM9002); the Humanities and Social Sciences and Management Promotion Fund of Northwestern Polytechnical University (No. RW201004). role in creating a gathering relationship; knowledge resources play the role of protection of intellectual assets; abundant capital resources become a push factor for the technology development and commercialization, and make both of them obtain multiplier effect. In the research of American Silicon Valley high-tech industry agglomeration phenomenon, Bahrml\&Evans $^{[4]}$ pointed out that the following six factors, including universities and research institutions, risk assets, supporting infrastructure, the high quality talent, entrepreneurial spirit and lead users interact with each other so as to successfully promote the formation of industrial cluster.

Some Chinese scholars believe that some of the industrial cluster phenomena have a direct relationship with privatization. They hold that the system innovation leads to the reduction of transaction costs and thus provides a deep level of protection for the formation of industrial agglomeration ${ }^{[5]}$.

Considering the above performance investigation of industrial clusters, there are two aspects of deficiency on the study of clusters: One is the lack of systematic theory framework analysis of cluster economy. Most of the researches are often limited to a certain angle, especially the lack of theoretical comprehensive and deepening research in cluster performance. The other is that the existing researches are limited to static analysis of cluster economic network structure and division of labor. They are lack of system analysis of cluster economy dynamic evolution, evolution mechanism of rise and fall. To study and solve the deficiencies in the above two aspects, is not only the key of research in industrial cluster in the future, but also what this paper attempts to focus on solving.

\section{ANALYSIS OF HIGH-TECH INDUSTRIAL CLUSTER IN SHAANXI PROVINCE}

\section{A. Index Selection and Data Source}

It has been proved theoretically and practically that, the agglomeration of many enterprises with higher connectivity and the related supporting agencies in high-tech industry reveals the cluster great agglomeration effect. The agglomeration effect basically behave in the technology, talent, risk investment, policy, etc.

In view of the data sources and accessibility, the high-tech industrial cluster performance is defined as the level of high- 
tech industry development, in addition, this paper uses four explanatory variables, which include human resources investment, the level of investment, technological innovation ability, government support to measure.

According to the analysis to establish the following model:

$$
Y=\beta_{0}+\beta_{1} \ln X_{1}+\beta_{2} \ln X_{2}+\beta_{3} \ln X_{3}+\beta_{4} X_{4}+\beta_{5} X_{5}+\mu
$$

TABLE I. THE DEFINITION OF VARIABLES IN THE MODEL

\begin{tabular}{|c|c|c|c|c|}
\hline Type & Name & $\begin{array}{l}\text { Specific target } \\
\text { and measuring }\end{array}$ & & Sign \\
\hline Explained variable & $\begin{array}{l}\text { The level } \\
\text { industrial } \\
\text { agglomeration }\end{array}$ & $\begin{array}{l}\text { The } \\
\text { of quotient, } \\
\text { which docation } \\
\text { by } \\
\text { employment }\end{array}$ & & \\
\hline \multirow{5}{*}{ Explaining variable } & $\begin{array}{l}\text { Human resource } \\
\text { investment }\end{array}$ & $\begin{array}{l}\text { Total employment } \\
\text { in Shaanxi high- } \\
\text { tech r industry, } \\
\text { which represented } \\
\text { by a log }\end{array}$ & $\ln X_{1}$ & \\
\hline & $\begin{array}{l}\text { The level o } \\
\text { investment }\end{array}$ & $\begin{array}{l}\text { Shaanxi high-tech } \\
\text { of industry } \\
\text { investment in fixed } \\
\text { assets }\end{array}$ & $\ln X_{2}$ & \\
\hline & \multirow{2}{*}{$\begin{array}{l}\text { Technological } \\
\text { innovation ability }\end{array}$} & $\begin{array}{l}\text { Patent accredit } \\
\text { quantity of Shaanxi } \\
\text { high-tech industry }\end{array}$ & $\ln X_{3}$ & \\
\hline & & $\begin{array}{llr}\text { Ratio of } & \text { output } \\
\text { value to } & \text { new } \\
\text { product } & & \end{array}$ & & \\
\hline & $\begin{array}{l}\text { Government } \\
\text { support }\end{array}$ & $\begin{array}{l}\text { Ratio of } \\
\text { government funds } \\
\text { of the R\&D funds }\end{array}$ & & \\
\hline
\end{tabular}

This section uses time series data in 1995-2010 to analysis. This data is from the "China Statistics Yearbook on high technology industry" and" China Statistical Yearbook", and it includes price deflator, like fixed investment of Shaanxi hightech industry. The base year is 1995 . In addition, this paper tackles the problem of some missing data by using interpolation.

\section{B. Model Parameter Estimation}

With the Eviews software, Estimation results of model can be expressed as:

$$
\begin{gathered}
Y=70.00080-5.999313 \ln X_{1}+0.110883 \ln X_{2}+ \\
0.399591 \ln X_{3}+3.632670 X_{4}+1.021844 X_{5}
\end{gathered}
$$

$$
R^{2}=0.99831 \overline{8}, R^{2}=0.947476, F=57.66910, D W=
$$

\subsection{2}

Since $\mathrm{R}^{2}$ is large and close to 1 , model fitting degree is very high. $F=57.66910$ is greater than the critical value, indicating that the regression equation established significantly under a level of $95 \%$. This analysis indicates that the significant linear correlation between the level of industrial agglomeration of
Shaanxi high-tech industry and the five explaining variables. But for the variations, $\ln \mathrm{X}_{1}, \ln \mathrm{X}_{2}$ and $\mathrm{X}_{5}$ have no significant influence on the overall average changes of explained variable $\mathrm{Y}$, and the coefficient of correlation, $\ln \mathrm{X}_{1}$, is irreconcilable with real economic significance, it shows that between each variables in model is likely to have serious multicollinearity. So it is necessary to make the appropriate adjustments.

1) By Stepwise Regression to Deal With the Multicollinearity

By correlation coefficient to analysis the situation between the explaining variables, it is found that there exists serious multicollinearity in the model explaining variables, as shown in Table II.

TABLE II. CORRELATION COEFFICIENTS CALCULATED BETWEEN THE EXPLANATORY VARIABLES

\begin{tabular}{|l|l|l|l|l|l|}
\hline & \multicolumn{1}{|c|}{$\ln \mathbf{X}_{\mathbf{1}}$} & \multicolumn{1}{|c|}{$\ln \mathbf{X}_{\mathbf{2}}$} & \multicolumn{1}{|c|}{$\boldsymbol{l n} \mathbf{X}_{\mathbf{3}}$} & \multicolumn{1}{c|}{$\mathbf{X}_{\mathbf{4}}$} & \multicolumn{1}{c|}{$\mathbf{X}_{\mathbf{5}}$} \\
\hline $\boldsymbol{X}_{\mathbf{1}}$ & 1 & 0.984375 & 0.932871 & 0.912366 & 0.138708 \\
\hline $\boldsymbol{X}_{\mathbf{2}}$ & 0.984375 & 1 & 0.930588 & 0.8956 & 0.064509 \\
\hline $\boldsymbol{X}_{\mathbf{3}}$ & 0.932871 & 0.930588 & 1 & 0.846462 & 0.035566 \\
\hline $\boldsymbol{X}_{\mathbf{4}}$ & 0.912366 & 0.8956 & 0.846462 & 1 & -0.03479 \\
\hline $\boldsymbol{X}_{\mathbf{5}}$ & 0.138708 & 0.064509 & 0.035566 & -0.03479 & 1 \\
\hline
\end{tabular}

By stepwise regression, I were to do a simple regression of $\mathrm{Y}$ on $\mathrm{X}$, respectively. We can see the sort of $\mathrm{R}^{2}$ is: $\mathrm{X}_{4}, \ln \mathrm{X}_{3}$, $\ln \mathrm{X}_{2}, \ln \mathrm{X}_{1}, \mathrm{X}_{5}$. Based on the $\mathrm{X}_{4}$, and after sequentially adding in the other variables with stepwise regression, I found that in addition to the $t$ test of the parameters, $\ln X_{2}, \ln X_{1}$, the rest were significantly. So the adjusted model for:

$$
\underset{1.142096 X_{5}}{\hat{Y}}=-0.317363+1.33746 X_{4}+0.552819 \ln X_{3}+
$$

$$
R^{2}=0.998318, R^{2}=0.947476, F=57.66910, D W=
$$

1.596132

\section{2) Test of Heteroscedaticity}

In order to ensure that the regression parameter estimators have good statistical properties, classic linear regression models need to meet the important assumption of homoscedasticity ${ }^{[6]}$. If not, the model is said to exist heteroscedasticity. The above model has been test with white test, as shown in Table III, and found that $\mathrm{nR}^{2}=5.434693<\lambda$ $0.025(4)=11.14$, even if the null hypothesis, which heteroscedasticity does not exist between the $\mathrm{Y}$ and $\ln \mathrm{X}_{3}, \mathrm{X}_{4}$, $\mathrm{X}_{5}$, accepted.

TABLE III.

WHITE TEST

\begin{tabular}{|l|l|l|l|}
\hline \multicolumn{4}{|c|}{ Heteroskedasticity Test:White } \\
\hline F-statistic & 0.342927 & Prob.F(9, 6) & 0.9273 \\
\hline Obs*R-squared & 5.434693 & Prob.Chi-Square(9) & 0.7949 \\
\hline Scaled explained SS & 1.984982 & Prob.Chi-Square(9) & 0.9917 \\
\hline
\end{tabular}




\section{3) Test of Autocorrelation}

If the variables have certain meanings in the order of time or space, there may exist the serial correlation, particularly in the study of the time series data, the data are often exhibited inherent autocorrelation ${ }^{[7]}$. If we allow the error term autocorrelation, but still retain the other classic assumption, then the OLS estimators of the model parameters is no longer BLUE, and hypothesis testing for regression parameters are no longer reliable ${ }^{[8]}$. Therefore, we need to examine and eliminate the autocorrelation, and make the model more credible.

Using D-W test in this paper, and given $\alpha=0.05, \mathrm{n}=16, \mathrm{k}=$ 3 , We know that $\mathrm{d}_{\mathrm{L}}=0.98, \mathrm{~d}_{\mathrm{U}}=1.54$ from the $\mathrm{D}-\mathrm{W}$ table, and $\mathrm{DW}=0.784020<\mathrm{d}_{\mathrm{L}}$ in the model. Apparently, random error term exists first order autocorrelation.

In order to eliminate the correlation, this paper used the Cochrane-Orcutt iterative method. $\rho=0.572464$ can be obtained from the model. Due to the small sample size in this paper, the Price-Winstein transformation is required, and then we can get the regression equation:

$$
\begin{aligned}
& \hat{Y}=-0.655407+0.61457 \ln \hat{X}_{3}{ }^{*}+1.40286 \hat{X}_{4}{ }^{*}+ \\
& 0.790279 \hat{X}_{5}{ }^{*}
\end{aligned}
$$

\section{4) Test of Economic Significance}

In this model, $\beta_{1}=0.61457, \beta_{2}=1.40286, \beta_{3}=0.790279$. The symbol of the estimated parameters is consistent with economic theory. It's shows that in the case of other factors unchanged, the marginal product of the high-tech industry patents accredit quantity in Shaanxi is 0.61457 . For every $1.40286 \%$ increase in the output rate of new products, on average, the level of industrial agglomeration, even if the location quotient, of hightech industry in Shaanxi Province will increase by $1 \%$. For every $0.790279 \%$ increase in ratio of government funds of the $\mathrm{R} \& \mathrm{D}$ funds, the level of industrial agglomeration, even if the location quotient, of high-tech industry in Shaanxi Province will increase by $1 \%$.

\section{Analysis}

Through the above regression analysis, we know that the overall situation of the model is good. It is safe to come to the conclusion that the patent accredit quantity, the output rate of new products, ratio of government funds of the R\&D funds have made effect on the level of industrial agglomeration of high-tech industry in Shaanxi Province.

The output rate of new products is the most influential factor on the level of industrial agglomeration. Meanwhile patent accredit quantity reflecting the technical innovation ability makes the minimal effect on the level of industrial agglomeration. It indicates that the input and output effect of Shaanxi science and technology is not obvious, the abilities of science and technology in promoting social development is not outstanding, which affects the Shaanxi high-tech industrial cluster effect.

As a high technology enterprise, it needs to strengthen the cultivation of independent innovation ability, accumulate industry scale and competitive strength through the introduction of the original innovation and integrated innovation, and create high-tech industry cluster with their own intellectual property rights.

Government support has a positive effect on Shaanxi high technology industrial cluster performance. It shows that the financial support of the government has formed powerful supplement on the high technology industry development in Shaanxi province, the government technology support for industry has formed a strong "backing".

Though, the government should make more efforts in policy research, market coordination etc. Through reasonable system arrangement and policy-making, the government needs to improve and perfect the function of government made in the high tech industrial clusters development, create transaction specification, competitive and orderly market system and market environment, provide material, legal and policy security for the promotion of high-tech industry cluster effect.

Investment in human resources playing an inconspicuous effect on the industrial agglomeration level, are removed in multiple colinearity tests. It proves that serious defects existing in Shaanxi province high technology industry human resources development.

Therefore, the government should adopt the means of "introducing foreign capital and establishing domestic connections", combine the talent introduction with selfcultivation multi-level innovative talents, accelerate the cultivation of talents and construction of professional talent team $^{[9]}$, provide a strong talent pool for the development of high technology industry cluster, and create value for the high technology industry agglomeration level of Shaanxi province.

the investment level variables making inconspicuous influence on Shaanxi high-tech industry cluster effect were removed in multiple colinearity tests. As we know, the higher high-tech industry investment level of a region is, the easier to attract high-tech enterprises assemble in this area, and the higher the high-tech industry agglomeration level will become $^{[10]}$. While we find that the fixed capital investment makes a small influence on the level of industrial agglomeration effect. One of the reasons for this is repeating distributions of Shaanxi high-tech industry cluster, duplication of investment caused, and the investment did not achieve the maximum use.

the government needs to make a good planning of industry regional layout, make reasonable layout of cluster development according to the distribution of cluster elements, avoid repeated construction and investment in the same area, and strive to make fully use of the investment.

\section{CONCLUSION}

To undertake a comprehensive study of the level of a region's high-tech industry development, we need synthetical consideration of both the government and enterprises. In this article, according to the characteristics of high-tech industry development in Shaanxi Province, I proposed a method to measure the performance of the high-tech industry cluster from four aspects of the technology, talent, risk investment, policy. 
This method broke through the previous perspective of a single level research, meanwhile, I undertook deepening and comprehensive study on the cluster performance by regression analysis. In addition, the other research about high-tech industrial clusters can also learn from this idea.

\section{REFERENCES}

[1] Weining Zhang, Xiumei Zhu, "High-tech industrial clusters innovation performance evaluation index system design,” Journal of Industrial Technological Economics, vol. 11, 2006, pp. 57-59.

[2] Friedman L, Sinuany S, "Scaling units via the canonical correlation analysis and the data envelopment analysis," European Journal of Operational Research, vol. 3, 1997, pp. 629-637.

[3] Sabourin V, Pinsonneault I, "Strategic formation of competitive high technology clusters," International Journal of Technology Management, vol. 13,No. 2, 1997, pp. 165-178.
[4] Bahrml H, Evans S, "Flexible re-cycling and high- technology entrepreneurship," California Management Review, vol. 37, 1995, pp. 62-89.

[5] Xiuwu Zhang, "The cases study of innovation influencing the regional high-tech industrial cluster,” Journal of Huaqiao University,vol. 2, 2010, pp. 58-65.

[6] Xiaoqin Yang, Jinping Yu, "Influencing factors of China's high-tech industrial agglomeration,” Technology Progress and Policy, vol.2, 2006, pp. 34-38.

[7] Shaoping Wang, Jisheng Yang, Zhigang Ouyang, Econometrics, Beijing: Higher Education Press, 2011, pp. 152.

[8] Heping Zuo, Jianren Yang, "Performance of China's ceramic industry cluster based on panel data empirical research," China industrial economics, No. 9, 2011, pp. 78-87.

[9] Qiuhong Wang, Xi Chen, "Study of High-tech Industry Cluster in China,” Research on Development, No. 6, 2011, pp. 101-104.

[10] Yuehua Zhang, Di Cao, Weixian Xue, "Effect Analysis of the high-tech industry cluster in Shaanxi Province,” vol. 11, 2009, pp. 32-38. 